\title{
Konsep pendidikan keluarga perspektif puritan teologis
}

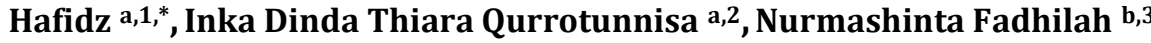 \\ *a Sekolah Tinggi Ilmu Tarbiyah Madani Yogyakarta, Indonesia; \\ b STAINU Temanggung, Indonesia. \\ ${ }^{1}$ dr.hafidz2020@gmail.com; ${ }^{2}$ tiaramas19@gmail.com; ${ }^{3}$ fadhilanunush@gmail.com \\ *Correspondent Author
}

\section{KATAKUNCI}

Keluarga

Pendidikan

Puritan teologis

\section{KEYWORDS}

Family

Education

Theological puritans
ABSTRAK

Makalah ini menjelaskan konsep pendidikan orang tua dalam keluarga dalam sudut pandang kaum puritan teologis. Dari kajian literatur diketahui bahwa lingkungan keluarga menjadi tempat yang pertama dan utama orangtua memberikan pendidikan dan anggota keluarga menerima pendidikan, disini terjadi proses take and give. Ayah dan ibu dalam keluarga menjadi pendidik pertama dalam proses perkembangan kehidupan anak. Orang tua tidak sekedar membangun silaturahmi dan melakukan berbagai tujuan berkeluarga untuk reproduksi, meneruskan keturunan, dan menjalin kasih sayang. Akan tetapi, tugas utama keluarga adalah menciptakan bangunan dan suasana proses pendidikan keluarga sehingga melahirkan generasi yang cerdas dan berakhlak mulia sebagai pijakan yang kokoh dalam menapaki kehidupan dan perjalanan anak manusia. Kenyataan tersebut ditopang temuan teori-teori yang mendukung pentingnya pendidikan keluarga sebagai dasar pertama pendidikan anak-anak. Pada sisi ini kaum puritan teologis mempunyai konsep pendidikan keluarga yang berbeda dari pendidikan mainstream yang ada saat ini. Disinilah fokus penelitian ini akan diarahkan.

\section{The concept of family education from the theological puritan} perspective

This paper describes the concept of parenting in the family from the point of view of theological puritans. From the literature review, it is known that the family environment is the first and foremost place for parents to provide education and family members to receive education, here there is a take and give process. Fathers and mothers in the family become the first educators in the process of developing children's lives. Parents do not just build relationships and carry out various family goals for reproduction, continuing offspring, and establishing affection. However, the main task of the family is to create a building and atmosphere for the family education process so as to give birth to a generation of intelligent and noble character as a solid footing in treading the life and journey of a human child. This fact is supported by the findings of theories that support the importance of family education as the first basis for children's education. On this side, theological puritans have a different concept of family education from mainstream education that exists today. This is where the focus of this research will be directed

This is an open-access article under the CC-BY-SA license. 


\section{Pendahuluan}

Keluarga sebagai sebuah lembaga pendidikan yang pertama dan utama. Keluarga diharapkan senantiasa berusaha menyediakan kebutuhan, baik biologis maupun psikologis bagi anak, serta merawat dan mendidiknya. Keluarga diharapkan mampu menghasilkan anak-anak yang dapat tumbuh menjadi pribadi, serta mampu hidup di tengah-tengah masyarakat. Sekaligus dapat menerima dan mewarisi nilai-nilai kehidupan dan kebudayaan. Menurut Selo Soemarjan(Indy et al., 2019), keluarga adalah sebagai kelompok inti, sebab keluarga adalah masyarakat pendidikan pertama dan bersifat alamiah. Dalam keluarga, anak dipersiapkan untuk menjalani tingkatan-tingkatan perkembangannya sebagai bekal ketika memasuki dunia orang dewasa, bahasa, adat istiadat dan seluruh isi kebudayaan, seharusnya menjadi tugas yang dikerjakan keluarga dan masyarakat didalam mempertahankan kehidupan oleh keluarga.

Dalam wahana keluarga, orang tua terutama ayah sebagai kepala keluarga dengan bantuan anggotanya harus mampu mempersiapkan segala sesuatu yang dibutuhkan sebuah keluarga. Seperti bimbingan, ajakan, pemberian contoh, kadang sanksi yang khas dalam sebuah keluarga, baik dalam wujud pekerjaan kerumahtanggaan, keagamaan maupun kemasyarakatan lainnya, yang dipikul atas seluruh anggota keluarga, atau secara individual, termasuk interaksi dalam pendidikan keluarga. Menurut Ki Hajar Dewantara(Yohana, 2017), keluarga adalah kumpulan individu yang memiliki rasa pengabdian tanpa pamrih, demi kepentingan seluruh individu yang bernaung di dalamnya. Begitu pentingnya keluarga dari kehidupan manusia bagi individu maupun sekelompok orang.

Anak tidak bisa dipisahkan dari keluarga, dengan keluarga orang dapat berkumpul, bertemu dan bersilaturahmi. Dapat dibayangkan jika manusia hidup tanpa keluarga. Tanpa disadari secara tidak langsung, telah menghilangkan fitrah seseorang sebagai makhluk sosial. Hal ini sejalan dengan pernyataan Selo Soemarjan, keluarga adalah sekelompok orang yang dipersatukan oleh pertalian kekeluargaan, perkawinan atau adopsi yang disetujui secara sosial dan pada umumnya sesuai dengan peranan-peranan sosial yang telah dirumuskan dengan baik.

Abdullah dan Berns juga memperkuat agrumen(Haryanti, 2017), bahwa keluarga adalah suatu kelompok sosial yang ditandai oleh tempat tinggal bersama kerja sama ekonomi, dan reproduksi. Di sisi lain, dalam konteks pengertian psikologis, keluarga dimaknai sebagai kumpulan orang yang hidup bersama dengan tempat tinggal bersama dan masing-masing orang yang terlibat di dalamnya merasakan adanya pertautan batin sehingga terjadi saling memperhatikan, saling membantu, bersosial dan menyerahkan diri.

Begitu pula dalam kaitan pandangan pedagogis.(Baharun, 2016) Keluarga adalah satu persekutuan hidup yang dijalin oleh kasih sayang antara pasangan dua jenis manusia yang dikukuhkan dengan pernikahan dengan maksud untuk saling menyempurnakan. Selain itu, keluarga menjadi tempat untuk mendidik anak agar pandai, berpengalaman, berpengetahuan, dan berperilaku dengan baik. Kedua orang tua harus memahami dengan baik kewajiban dan tanggung jawab sebagai orang tua. Orang tua (ayah dan ibu)tidak hanya sekedar membangun silaturahmi dan melakukan berbagai tujuan berkeluarga, seperti reproduksi, meneruskan keturunan, menjalin kasih sayang dan lain sebagainya. Tugas keluarga sangat urgen, yakni menciptakan suasana dalam keluarga proses pendidikan yang berkelanjutan(continues progress)guna melahirkan generasi penerus (keturunan) yang cerdas dan berakhlak (berbudi pekerti yang baik). Baik di mata orang tua, dan masyarakat.

\section{Metode}

Penelitian ini digolongkan ke dalam jenis penelitian studi pustaka atau literer(Baharun, 2016), yaitu dalam proses perolehan data sesuai dengan sasaran atau masalah penelitian yang diperlukan sebuah informasi yang selengkap- lengkapnya atau sedalamdalamnya mengenai gejala-gejala yang ada dalam lingkup obyek penelitian. Dari gejala-gejala penelitian 
yang ada dalam penelitian ini bukanlah satu-satunya yang berdiri, melainkan saling berkaitan antara satu sama lain dalam kesatuan yang menyeluruh yang biasanya dikenal dengan pendekatan . Dalam penelitian ini, pengumpulan data menggunakan tiga metode utama yaitu : wawancara, observasi dan dokumentasi.

\section{Hasil dan Pembahasan}

\section{Pendidikan Keluarga}

Ontologi Pendidikan Keluarga. Dalam berbagai literatur, para ahli memberikan berbagai sudut pandang tentang pengertian pendidikan keluarga. Misalnya Mansur, (Setiani, 2018b)mendefinisikan pendidikan keluarga adalah proses pemberian nilai-nilai positif bagi tumbuh kembangnya anak sebagai fondasi pendidikan selanjutnya. Selain itu, Abdullah(Sutrisno, 2017) juga mendefinisikan pendidikan keluarga adalah segala usaha yang dilakukan oleh orang tua berupa pembiasaan dan improvisasi untuk membantu perkembangan pribadi anak. Pendapat lain yang dikemukakan oleh an Nahlawi, Hasan Langgulung (Musmualim \& Miftah, 2016) memberi batasan terhadap pengertian pendidikan keluarga sebagai usaha yang dilakukan oleh ayah dan ibu sebagai orang yang diberi tanggung jawab untuk memberikan nilai-nilai, akhlak, keteladanan dan kefitrahan.

Ki Hajar Dewantara merupakan salah seorang tokoh pendidikan Indonesia, juga menyatakan bahwa alam keluarga bagi setiap orang (anak) adalah alam pendidikan permulaan. Untuk pertama kalinya, orang tua (ayah maupun ibu) berkedudukan sebagai penuntun (guru), sebagai pengajar, sebagai pendidik, pembimbing dan sebagai pendidik yang utama diperoleh anak. Maka tidak berlebihan kiranya manakala merujuk pada pendapat para ahli di atas konsep pendidikan keluarga. Tidak hanya sekedar tindakan (proses), tetapi ia hadir dalam praktek dan implementasi, yang dilaksanakan orang tua (ayah-ibu) degan nilai pendidikan pada keluarga.

Perlu diketahui, mayoritas orang tua minim pengetahuan tentang konsep pendidikan keluarga. Hal tersebut masih belum disadari para orang tua (ayah dan ibu) dalam praktek kesehariannya. Padahal mereka telah menjalankan fungsi keluarga dalam pendidikan anakanaknya. Pada hakikatnya, fungsi keluarga adalah sebagai pendidikan budi pekerti, sosial, kewarganegaraan, pembentukan kebiasaan dan pendidikan intelektual anak. Mollehnhaur dalam Abdullah(Keluarga et al., 2016) membagi tiga fungsi keluarga dalam pendidikan anak, yaitu:

Pertama, Fungsi kuantitatif, yaitu menyediakan bagi pembentukan perilaku dasar, artinya keluarga tidak hanya menyediakan kebutuhan dasar fisik anak, berupa pakaian, makanan dan minuman, serta tempat tinggal yang layak. Akan tetapi, keluarga dituntut untuk menyediakan dan memfasilitasi ketersediaan dasar-dasar kebaikan, berupa perilaku, etika, sopan santun dan pembentukan karakter anak yang santun dan berakhlak baik sebagai fitrah manusia yang hakiki.

Kedua, Fungsi-fungsi selektif, yaitu menyaring pengalaman anak dan ketidaksamaan posisi kemasyarakatan karena lingkungan belajar. Artinya pendidikan keluarga berfungsi sekaligus memerankan diri sebagai fungsi kontrol pengawasan terhadap diri anak akan berbagai informasi yang diterima anak. Terutama anak usia nol tahun hingga lima tahun yang belum memiliki pengetahuan dan pengalaman. Sehingga diharapkan mampu membedakan mana yang baik dan buruk. Oleh sebab itu, keluarga (ayah dan ibu) berkewajiban memberikan informasi dan pengalaman yang bermakna. Berupa pengalaman belajar secara langsung maupun tidak langsung, diharapkan pengalaman tersebut mampu diserap dan ditransformasi dalam diri anak.

Ketiga, Fungsi pedagogis, yaitu mewariskan nilai-nilai dan norma-norma. Artinya pendidikan keluarga berfungsi memberikan warisan nilai-nilai yang berkaitan dengan 
aspek kepribadian anak. Tugas akhir pendidikan keluarga tercermin dari sikap, perilaku dan kepribadian (personality) anak dalam kehidupan sehari-hari yang ditampilkan. Sementara itu, ternyata fungsi keluarga bukan sebatas itu, misalnya Berns,(Setiani, 2018a) ia mengemukakan fungsi keluarga, yaitu fungsi reproduksi, melaksanakan pendidikan dan sosialisasi di masyarakat, membangun aturan-aturan sosial, melakukan tindakan ekonomi, dan membangun dan mendukung proses perkembangan emosi anak-anak.

Ontologi Puritan Teologis. Konsep gagasan yang diusung oleh Muhammad bin Abdul Wahab merupakan gerakan penerus ide-ide dari pembaharuan Ibnu Taimiyah(Basit, 2018). Pengaruh gerakan Wahabi teradap gerakan-gerakan reformis Islam sesudahnya, notabene menggiring pada konsep ajaran kembali kepada sumber ajaran Islam yang asli yaitu Al Qur'an dan Al Hadits, kemudian mendorong perlunya dimunculkan kembali semangat ijtihad dan pelarangan terhadap taqlid buta. Oleh sebab itu tidak berlebihan jika dikatakan, bahwa apabila dilacak gagasan-gagasan maupun gerakan-gerakan pembaharuan Islam dewasa ini, pada akhirnya akan sampai kepada gerakan Wahabiyah. Penyimpangan teologis yang terjadi pada umat Islam pada waktu itu menggugah pikiran Muhammad bin Abdul Wahhab untuk meluruskan (tashfiyah/puritan) aqidah menyimpang saat itu, diantaranya pengkultusan terhadap kuburan-kuburan para wali dan orang-orang saleh serta praktek-praktek yang bersangkutan dengan keyakinan tersebut(syirik). Beliau membawa penafsiran kembali tradisi sufi pada kesimpulan logis fundamentalis (sunnah) dan menolak seluruh praktek-praktak peribadatan sufi (bidah), karena mempunyai penemuan-penemuan yang tak sehat. Penolakan terhadap sufisme ini, mengeluarkan semua fundamentalisme muslim lain, baik yang mendahuluinya maupun para pengganti pada generasi kemudian. Gerakan Wahabi memberikan corak khas pada gerakan rekonstruksi sosio-moral abad ke-18 $M$ yang menolak sinkritisme sufi abad pertengahan. Kiprah Muhammad bin Abdul Wahhab merupakan kontribusi yang cukup besar bagi perkembangan ideologi Islam, yaitu upaya untuk menyelamatkan degradasi moral dan kekotoran tauhid yang menimpa umat Islam pada masanya. Faktanya, hal itu telah membangkitkan semangat baru ke arah keselamatan dan kesejahteraan umat Islam menuju arah yang lebih baik.

\section{Pendidikan Keluarga Puritan Teologis}

Hakikat Pendidikan Puritan Teologis. Pendidikan keluarga memiliki arti yang sangat luas, sebagaimana yang telah disampaikan dalam al-Qur'ān dan hadits Nabi Saw. Paling tidak bisa diambil kesimpulan bahwa pendidikan berusaha mengarahkan fitrah manusia pada potensi yang paling sempurna dengan proses yang bertahap, Serta tidak bertentangan dengan sumber-sumber hukum Islam.

Dalam pendidikan keluarga haruslah diperhatikan secara seimbang antara pendidikan jasmani dan rohani. Kedua hal tersebut tidak dapat ditinggalkan dan dipisahkan dalam pendidikan. Pentingnya pendidikan dalam keluarga karena sarana apapun selain keluarga tidak dapat menggantikan vitalnya peran keluarga. Khususnya sistem pemeliharaan anak, yang memang ada sebagaian lembaga bermaksud hendak menggantikan sistem keluarga yang suci, tenang, dan lurus yang telah dijadikan demikian oleh Allah untuk manusia.

Oleh sebab itu hanya terdapat dalam tatanan sosial Islam yang Allah kehendaki untuk dilakukan umat Muslim secara total dan merasakan kenikmatan, kesejahteraan yang lengkap di bawah naungan yang berbasis keluarga dimana tercurah perhatian yang besar yang peranannya sangat penting.

Dalam konsep puritan teologis pendidikan keluarga haruslah bisa memberikan solusi terbaik serta pemecahan masalah kepada anak didik dalam mengarungi kehidupannya, baik masa sekarang maupun masa yang akan datang. Pendidikan keluarga harus memiliki kerangka pokok, metode dan prinsip-prinsip para pendidiknya. Diperlukan pula seni dan kiat-kiat khusus dalam mendidik karena pendidikan bukanlah hal yang mudah dan spontan. Melainkan dibutuhkan ilmu yang memadai untuk melaksanakan pendidikan yang baik. Dan pendidikan yang baik adalah yang sesuai dengan al-Qur'ān dan hadis Rasulullah shallallaahu 
alaihi wasallam.

Keluarga membentuk generasi-generasi baru di dalam kebudayaan, tradisi serta evolusi yang lebih jauh pada peradaban manusia. Ia memberi pedoman sistem keamanan sosial ekonomi, memperkuat dorongan manusia untuk mengembangkan kadar usaha serta kemajuan sosial. Ia penerus peradaban serta jembatan penghubung yang memungkinkan generasi baru memasuki masyarakat. Ia adalah jalinan yang mengaitkan masa lalu, masa kini dan masa datang, sedemikian rupa sehingga perubahan sosial dapat berjalan melalui proses yang sehat dan tentram. Di satu sisi di dalam keluarga ditandaskan bagaimana hubungan anak dengan lingkungan. Di sisi lain keluarga bagi mereka untuk meningkatkan peran budaya dan ideologi di dunia, baik untuk saat ini maupun masa mendatang. Oleh karena itu jika institusi ini diperlemah atau bahkan dihilangkan maka tak pelak lagi masa depan kebudayaan dan peradaban manusia akan terancam.

\section{Tujuan Pendidikan Keluarga Puritan Teologis}

Ada tujuh materi pendidikan keluarga yang harus ditanamkan oleh orangtua yaitu: Pertama, Pendidikan Keimanan. Yang dimaksud dengan pendidikan Iman adalah, mengikat anak dengan dasar-dasar iman saat ia mampu berfikir, membiasakannya dengan rukun Islam saat ia mulai dapat memahami, dan mengajarkan prinsip-prinsip syariat Islam yang indah saat ia sudah mampu membedakan (tamyiz). Dengan kata lain pendidikan iman dapat diartikan dengan pendidikan akidah yang merupakan proses pembinaan dan pemantapan kepercayaan dalam diri seseorang sehingga menjadi akidah yang kuat dan benar.

Dasar-dasar iman adalah segala sesuatu yang ditetapkan melalui informasi yang benar, berupa hakikat iman dan hal-hal gaib, seperti iman kepada Allah, iman kepada malaikat, iman kepada kitab-kitab samawi, iman kepada semua rasul, iman kepada pertanyaan dua malaikat, beriman kepada azab kubur, kebangkitan, perhitungan amal, surga, neraka, dan hal-hal ghaib lainnya.

Hendaknya seorang pendidik menumbuhkan anak dengan pendidikan Islam ini sejak dini, dengan dasar-dasar ajaran Islam, agar ia terikat dengan Islam dalam segala aspeknya, baik akidah, ibadah, dan segala sesuatu yang terkait dengan sistem dan metodenya. Sehingga setelah itu ia tidak mengenal adanya agama selain Islam, imam selain Al Quranul Karim, pemimpin dan panutan lain selain Rasulullah shallallahu alaihi wasallam.

Ini semua adalah pemahaman pendidikan Islam yang disandarkan pada pesan-pesan dan petunjuk Nabi shallallahu alaihi wasallam. Dalam mengajarkan dasar-dasar iman, rukun Islam, dan aturan hukum pada anak. Sebagaimana petunjuk dan wasiat Rasulullah shallallahu alaihi wasallam. Yaitu: Pertama, Orang tua bertanggung jawab membimbing anaknya atas dasar pemahaman dan pendidikan Iman sesuai dengan ajaran Islam. Dengan cara membuka kehidupan anak dengan kalimat tauhid ketika lahir. Hal ini dimaksudkan agar kalimat tauhid dan syiar Islam itu menjadi yang pertama masuk ke dalam pendengaran anak, kalimat pertama yang diucapkan oleh lisannya dan lafal pertama yang dipahami anak.

Kedua, yaitu mengenalkan hukum halal dan haram.(Rahmadyansyah, 2015) Apabila anak sejak memasuki masa baligh telah memahami hukum-hukum halal dan haram,disamping telah terikat dengan hukum-hukum syariat, maka untuk selanjutnya, Ia tidak akan mengenal hukum lain. Ketiga ialah, mengajarkan tata cara beribadah (perintah shalat), dapat menyamakan dengan puasa dan haji. Latih anak-anak untuk melakukan puasa jika mereka kuat, dan haji jika bapaknya mampu. Hal ini dengan maksud agar anak dapat mempelajari hukum-hukum ibadah ini sejak masa pertumbuhannya. Sehingga ketika anak tumbuh besar, ia telah terbiasa melakukan dan terdidik untuk mentaati Allah, melaksanakan hak Nya, bersyukur kepada Nya, kembali kepada Nya, berpegang teguh kepada Nya, bersandar kepada Nya dan berserah diri kepada Nya. Disamping itu, anak akan mendapatkan kesucian rohani, kesehatan jasmani, kebaikan akhlaq, perkataan dan perbuatan di dalam ibadahibadah ini.

Keempat adalah mendidik anak untuk mencintai Nabi, ahlul baitnya, dan Al Quran. 
Berbicara tentang cinta kepada Rasulullah shallallahu alaihi wasallam, dan ahli baitnya, perlu diajarkan pula kepada mereka sejarah Nabi dan sahabat. Dimaksudkan agar anakanak mampu meneladani perjalanan hidup orang-orang terdahulu, baik mengenai pergerakan, pemikiran, kepahlawanan maupun jihad mereka, agar mereka juga memiliki keterkaitan sejarah, baik perasaan maupun kejayaannya dan juga agar mereka terikat dengan Al-Quran, baik semangat, metode maupun bacaannya.

Ringkasnya, tanggung jawab pendidikan Iman itu sungguh merupakan tanggung jawab terpenting bagi para pendidik, orang tua. Sebab, hal itu merupakan sumber segala keutamaan dan kesempurnaan. Bahkan ia adalah pangkal dasar bagi anak-anak untuk memasuki pintu gerbang Iman dan meniti jembatan Islam. Tanpa pendidikan itu, anak tidak akan memiliki rasa tanggung jawab, tidak dapat dipercaya, tidak mengenal tujuan, tidak mengerti nilai-nilai kemanusiaan yang mulia dan tidak mampu meneladani sesuatu yang paling luhur. Akhirnya ia hidup seperti binatang, yang hanya mempunyai keinginan untuk menutupi rasa laparnya, memuaskan tuntutan nalurinya, mengejar kesenangan seluruh hawa nafsunya, dan bergaul bersama orang-orang jahat yang berlumuran dosa. Dalam situasi seperti ini, anak akan masuk dalam kelompok kafir yang sesat dan selalu menghalalkan segala cara.

Pendidikan Akhlak. Yang dimaksud pendidikan akhlak(Bafadhol, 2017) adalah sejumlah prinsip-prinsip akhlak dan nilai-nilai moral yang harus ditanamkan kepada anakanak, agar bisa dijadikan kebiasaan oleh anak sejak dini, lalu meningkat baligh dan perlahan-lahan beranjak dewasa. Arti pendidikan akhlak adalah proses pembinaan budi pekerti anak sehingga menjadi budi pekerti yang mulia (akhlak karimah).

Tentunya, prinsip-prinsip akhlak dan nilai-nilai moral itu merupakan salah satu buah dari iman yang tertanam kokoh, dan pertumbuhan agama yang benar. Orang tua bertanggung jawab menanamkan dan melatih anak-anaknya untuk berperilaku mulia dalam kehidupannya. Sebagaimana sabda Rasulullah shallallahu alaihi wasallam yang artinya "Tidak ada suatu pemberian yang diberikan oleh seorang ayah kepada anaknya yang lebih utama dari pada budi pekerti yang baik." Ibnu Majah meriwayatkan dari Ibnu Abbas r.a bahwa Rasulullah shallallahu alaihi wasallam bersabda yang artinya "Muliakanlah anak-anak kalian dan didiklah mereka dengan budi pekerti yang baik."

Pendidikan Fisik. (Hariadi, 2015)Di antara tanggung jawab besar yang dibebankan Islam kepada para pendidik, yaitu para orang tua (ayah dan ibu) dan para guru adalah tanggung jawab pendidikan fisik, agar mereka dapat membesarkan anak dengan sebaik-baiknya, dimana anak memiliki fisik yang kuat, tubuh yang sehat, dan berpenampilan sehat.

Dalam pendidikan ini orang tua bertanggung jawab membina anak-anak agar memiliki fisik yang kuat, sehat, bergairah dan bersemangat dengan cara-cara tersebut di bawah ini: Kewajiban menafkahi keluarga dan anak "...Dan kewajiban ayah memberi makan dan pakaian kepada para ibu dengan cara ma'aruf...” (QS. Al-Baqarah; 233). Mengikuti pola makan, minum, dan istirahat yang sehat. “...makan dan minumlah, tetapi jangan berlebihan..."(Q.S. AlAraf: 31). Menjaga diri dari wabah penyakit menular. Berobat untuk menyembuhkan penyakit. Membiasakan anak berolahraga.

Sebagaimana Rasulullah shallallahu alaihi wasallam bersabda yang artinya "Orang mukmin yang kuat adalah lebih baik dan lebih dicintai Allah dari pada orang mukmin yang lemah, dan dalam setiap kebaikan jagalah sesuatu yang memberikan manfaat kepadamu, dan memohonlah kepada Allah dan jangan melemah. Apabila sesuatu menimpamu maka jangan katakan "kalaupun ini kulakukan maka akan terjadi begini dan begini". Akan tetapi ucapkanlah" Allah yang telah menentukan, dan apa yang dikehendaki Nya akan dilakukan Nya. Sesungguhnya perkataan "kalau" tersebut dapat membuka perbuatan syaitan".

Pendidikan Intelektual.(Rapika \& Sari, 2019) Yang dimaksud dengan pendidikan intelektual adalah membentuk dan membina pikiran anak dengan hal-hal yang bermanfaat, berupa ilmu-ilmu syar'i, ilmu pengetahuan dan budaya modern, pemikiran yang mencerahkan, dan kebudayaan. Diharapkan anak akan matang pikirannya serta menjadi orang yang berilmu dan berbudaya. 
Tanggung jawab ini tidak kurang pentingnya dari tanggung jawab lain yang telah dibahas sebelumnya, yaitu tanggung jawab iman, akhlak, dan fisik. Pendidikan iman meletakkan dasar-dasarnya. Pendidikan fisik merupakan persiapan dan pembentukan, dan pendidikan akhlak adalah penanaman akhlak dan pembiasaan dengannya. Sedangkan pendidikan intelektual berfungsi menyadarkan, mencerahkan, mengajarkan, dan membudayakan.

Pendidikan Mental/Psikis. Pendidikan psikis (Susanti, 2018)dimaksudkan untuk mendidik anak sejak ia mampu berpikir untuk berwatak berani, berterus terang, perkasa, merasa sempurna, senang berbuat baik pada orang lain, mampu mengontrol emosi, serta memiliki semua keutamaan jiwa dan akhlak.

Berikut ini adalah contoh-contoh bagaimana cara As-Salafush shalih mendidik anak-anak mereka untuk berani dan terhindar dari sifat minder. Abdullah bin Umar r.a ketika itu dia belum mencapai usia baligh bahwa Rasulullah shallallahu alaihi wasallam bersabda yang artinya "Sesungguhnya di antara pohon-pohon itu ada pohon yang daunnya tidak jatuh, dan pohon itu bagai seorang muslim. Katakanlah, pohon apakah itu?" Kemudian orang-orang menerka pohon itu adalah pohon padang pasir. Abdullah bin umar berkata: Aku menerka bahwa pohon itu adalah pohon kurma, tapi aku malu mengatakannya". Orang-orang berkata: "katakanlah kepada kami, pohon apakah itu wahai Rasulullah SAW? Beliau menjawab:"Pohon itu adalah pohon kurma." (H.R Bukhari dan yang lainnya)

Demikianlah Rasulullah shallallahu alaihi wasallam, dan para sahabat memperlakukan anak-anak. Mereka memberi semnagat agar anak-anak berani berbicara, dan memberi kesempatan untuk mengambil sebuah keputusan. Yang dengan demikian, akan membangkitkan rasa percaya diri anak, terhindar dari rasa takut dan minder, walau di hadapan orang dewasa sekalipun.

Pendidikan Sosial. Yang dimaksud dengan pendidikan sosial(Khoiruddin, 2018) adalah mendidik anak sejak dini untuk komit dengan etika-etika sosial yang baik dan dasar-dasar jiwa yang luhur, yang bersumber dari akidah Islam yang abadi dan perasaan iman yang dalam. Dengan demikian si anak dapat hidup ditengah masyarakat dengan pergaulan dan adab yang baik, pemikiran yang matang dan bertindak secara bijaksana.

Tidak disangsikan lagi bahwa tanggung jawab ini merupakan tanggung jawab terpenting bagi para pendidik dan orang tua di dalam mempersiapkan anak, baik pendidikan keimanan, moral maupun kejiwaan. Sebab, pendidikan sosial ini merupakan manifestasi perilaku dan watak yang mendidik anak untuk menjalankan kewajiban, tata krama, kritik sosial, keseimbangan intelektual, politik dan pergaulan yang baik bersama orang lain.

Anak-anak perlu dilatih bermasyarakat. Dikenalkan dengan orang-orang di sekitarnya, dilatih bagaimana cara bergaul yang benar, dan selalu berlaku baik kepada siapapun, menyayangi sesama termasuk kepada makhluk-makhluk Allah yang lain di muka bumi ini. Menghormati yang lebih tua, membimbing yang lebih muda, dan memelihara hak orang lain, serta melaksanakan adab-adab sosial yang mulia. Seperti dalam sabda Rasulullah shallallahu alaihi wasallam yang artinya "Seorang muslim adalah saudara bagi muslim yang lainnya, ia tidak boleh menganiaya, tidak boleh menyerahkannya (kepada musuh), tidak boleh mengecewakannya, dan tidak boleh menghinakannya. Cukuplah seseorang dianggap jahat apabila menghinakannya. Cukuplah seseorang dianggap jahat apabila menghinakan saudaranya yang muslim. Setiap muslim bagi muslim yang lainnya adalah haram darahnya, harinya, dan kehormatannya......"

Pendidikan Seks. Dengan mengajarkan dan menerangkan kepada anak serta menyadarkannya mengenai berbagai masalah yang berkaitan dengan seks, naluri terhadap lawan jenis dan perkawinan. Ini dilakukan agar ketika anak sudah tumbuh dewasa dan memahami masalah-masalah kehidupan, ia dapat mengetahui apa yang halal dan apa yang haram, dan memiliki akhlak, perilaku serta kebiasaan yang Islami. Ia tidak akan jatuh karena mengikuti nafsu syahwat dan pola hidup bebas('free sex'). 


\section{Simpulan}

Keluarga adalah lembaga yang utama dan pertama bagi proses awal pendidikan anakanak untuk mengembangkan potensi yang dimiliki seorang anak ke arah pengembangan kepribadian diri yang positif dan baik. Orang tua (ayah dan ibu) memiliki tanggung jawab yang besar dalam mendidik anggota keluarga. Fungsi-fungsi dan peran orang tua tidak hanya sekedar memenuhi kebutuhan fisik anak berupa kebutuhan makan dan minum, pakaian, tempat tinggal, tapi juga tanggung jawab orang tua jauh lebih penting dari itu adalah memberi perhatian, bimbingan, arahan, motivasi, dan pendidikan, serta penanaman nilai.

Alternatif pendidikan keluarga puritan teologis menawarkan konsep pendidikan yang terarah dan terpadu. Mengedepankan penanaman nilai-nilai ilahiah dan insaniah yang seimbang(tawazun) sebagai entitas dari habluminallah (vertikal transedental) dan habluminannas (horisontal universal). Meskipun terkesan rigid dan jumud tapi pendalaman terhadap sumber sakral teologis(Al Quran dan Hadits) dilakukan demi terciptanya pemurnian keyakinan(tashfiyah) sebagaimana yang telah digagas tokoh pendahulunya yaitu Muhammad bin Abdul Wahab yang senantiasa teguh berpegang pada semangat perenialis tekstual. Meyakini secara penuh bahwa jalan yang ditempuhnya(puritan teologis) akan membawa keselamatan bagi umat hingga berakhirnya alam semesta ini(kiamat).

Sebuah gagasan logis fundamentalis khususnya di masa dimana degradasi moral dan kehancuran kepribadian anak didik menjadi taruhan yang tak terelakkan saat ini. Konsep pendidikan keluarga puritan teologis bisa menjadi kontribusi yang mencerahkan peradaban khususnya keluarga muslim.

\section{Daftar Pustaka}

Bafadhol, I. (2017). Pendidikan Akhlak dalam Persfektif Islam. Jurnal Edukasi Islami Jurnal Pendidikan Islam, 06(12), 45-61.

Baharun, H. (2016). Pendidikan Anak dalam Keluarga: Telaah Epistemologis. Jurnal Pedidikan, 3(2), 96-107.

Basit, A. (2018). Muhammad Bin Abdul Wahhab: Pemikiran Teologi Dan Tanggapan Ulama Mengenai Pemikirannya. Tazkiya, 19(2), 54.

Hariadi, H. (2015). Pengembangan Pendidikan Karakter Dalam Pendidikan Jasmani Dan Olahragapada Pendidikan Anak Usia Dini. PARAMETER: Jurnal Pendidikan Universitas Negeri Jakarta, 27(II), 93. https://doi.org/10.21009/parameter.272.01

Haryanti, D. (2017). Keterlibatan Keluarga Sebagai Mitra Pendidikan Anak. Noura, 1(1), 48-65.

Indy, R., Waani, F. J., \& Kandowangko, N. (2019). Peran Pendidikan Dalam Proses Perubahan Sosial Di Desa Tumaluntung Kecamatan Kauditan Kabupaten Minahasa Utara. HOLISTIK, Journal Of Social and Culture, 12(4), 1-21. https://ejournal.unsrat.ac.id/index.php/holistik/article/view/25466

Keluarga, P., Untuk, M., Lahan, P., \& Di, G. (2016). Integrasi Pendidikan Lingkungan Dengan Tri-Pusat. $2011,325-340$.

Khoiruddin, M. (2018). Pendidikan Sosial Berbasis Tauhid dalam Perspektif Al-Qur'an. Aplikasia: Jurnal Aplikasi Ilmu-Ilmu Agama, 18(1), 51. https://doi.org/10.14421/aplikasia.v18i1.1385

Musmualim, M., \& Miftah, M. (2016). PENDIDIKAN ISLAM DI KELUARGA DALAM PERSPEKTIF DEMOKRASI (Studi Pemikiran Hasan Langgulung dan Abdurrahman an Nahlawi). JURNAL PENELITIAN, 10(2). https://doi.org/10.21043/jupe.v10i2.1781

Rahmadyansyah. (2015). Internalisasi Nilai-nilai Keteladanan Orang Tua pada Anak Prasekolah. Jurnal MUDARRISUNA, 4(2), 763-782. http://jurnal.arraniry.ac.id/index.php/mudarrisuna/article/download/633/521

Rapika, S., \& Sari, A. P. (2019). Pengaruh Kepribadian Dan Kemampuan Intelektual Terhadap Kompetensi Guru Di Smkn 3 Kota Bengkulu. Managament Insight: Jurnal Ilmiah Manajemen, 12(2), 64-76. https://doi.org/10.33369/insight.12.2.64-76 
Setiani, R. E. (2018). Pendidikan Anak Dalam Keluarga. YINYANG: Jurnal Studi Islam, Gender Dan Anak, 13(1), 105-116. https://doi.org/10.24090/yinyang.v13i1.2018.pp105-116

Susanti, S. S. (2018). Kesehatan Mental Remaja Dalam Perspektif Pendidikan Islam. As-Salam, Vol 7 No 1 (2018): PENDIDIKAN, HUKUM \& EKONOMI SYARIAH, 1-20.

http://ejournal.staidarussalamlampung.ac.id/index.php/assalam/article/view/101

Sutrisno, A. (2017). Metode Pendidikan Anak dalam Keluarga Menurut Abdullah Nashih Ulwan dan Relevansinya dengan pendidikan Anak dalam Keluarga di Kelurahan Majapahit Kota Lubuklinggau. 2(2), 203-215.

Yohana, N. (2017). Konsepsi Pendidikan dalam Keluarga Menurut Pemikiran Ki Hadjar Dewantara dan Hasan Langgulung. Jurnal Ilmiah Kajian Islam, 2(1), 1-18. 